\title{
ANALISIS SUMBER DAN PENGGUNAAN DANA PT.BUMI SARANA UTAMA CABANG PALU
}

\author{
Adelina \\ Darman \\ Program Studi S1 Manajemen Fakultas Ekonomi Universitas Tadulako \\ email: adhel.bucu@gmail.com; Darman_tadulako@untad.ac.id
}

\begin{abstract}
The objectives of this research are (1) to find out and analyzing the policy of the source and the use of cash funds at PT. Bumi Sarana Utama Palu Branch; and (2) To find out and analyzing the policy of the source and the use of working capital funds at PT. Bumi Sarana Utama Palu Branch. This research is a descriptive. The results of the research show that: (1) The analysis result of the source and the use of cash at PT. Bumi Sarana Utama Palu branch period 2016 to 2018 show that the source of cash is obtained by the company is greater than the use of cash so at the value of the financing structure or expenditure carried out by PT. Bumi Sarana Utama Palu branch is correct, because the view of liquidity is none long-term funding needs that are spent with short-term funding sources, (2) The analysis result of the source and the use of working capital funds at PT. Bumi Sarana Utama Palu branch for the period of 2016 to 2018 show that the source and the use of working capital funds is efficient, where working capital has increased every year as well as profits earned through operations the company can be maintained every year.
\end{abstract}

Keywords: Sources, Uses, Funds

\begin{abstract}
Abstrak
Tujuan penelitian ini untuk: (1) Mengetahui dan menganalisis kebijakan sumber dan penggunaan dana kas pada PT. Bumi Sarana Utama Cabang Palu dan (2) Mengetahui dan menganalisis kebijakan sumber dan penggunaan dana modal kerja pada PT. Bumi Sarana Utama Cabang Palu. Penelitian ini merupakan penelitian deskriptif. Hasil dari penelitian ini menunjukkan bahwa : (1) Hasil analisis sumber dan penggunaan kas pada pada PT. Bumi Sarana Utama Palu periode tahun 2016-2018, menggambarkan bahwa sumber kas yang diperoleh perusahaan lebih besar daripada penggunaan kas perusahaan sehingga di nilai struktur pembiayaan atau pembelanjaan yang dilakukan oleh PT. Bumi Sarana Utama Cabang Palu sudah tepat, karena dari pandangan likuiditas tidak ada kebutuhan dana jangka panjang yang dibelanjai dengan sumber dana jangka pendek, (2) Hasil analisis sumber dan penggunaan modal kerja pada PT. Bumi Sarana Utama Cabang Palu periode tahun 2016-2018, menggambarkan bahwa sumber dan penggunaan modal kerja sudah efisien, dimana modal kerja mengalami kenaikan setiap tahunnya begitu juga dengan laba yang didapatkan melalui operasional perusahaan dapat dipertahankan dalam setiap tahunnya.
\end{abstract}

Kata Kunci: Sumber, Penggunaan, Dana.

\section{PENDAHULUAN}

Keberhasilan dalam mempertahankan hidup dan mendapatkan laba adalah tujuan dari setiap perusahaan. Agar tujuan tersebut dapat tercapai dengan baik maka manajemen perusahaan mempunyai tanggung jawab utama membuat perencanaan, melakukan pengendalian dan menjaga sumber daya yang ada di dalam perusahaan.

Masalah yang sering dihadapi perusahaan adalah masalah keuangan bagaimana seorang manajer keuangan mencari sumber dan penggunaan dana baik dalam artian kas maupun modal kerja. Hal ini disebabkan karena setiap perusahaan didalam menjalankan kegiatan usahanya selalu memerlukan dana guna menunjang kegiatan operasionalnya sehari-hari. Dana sangat diperlukan dan menjadi salah satu bagian aktiva yang sangat penting dalam perusahaan, perusahaan tidak dapat memenuhi kebutuhannya tanpa adanya dana perusahaan guna menjalankan aktivitasnya. Manajer keuangan dituntut untuk mengawasi sumber dana yang dibutuhkan pada berbagai pilihan 


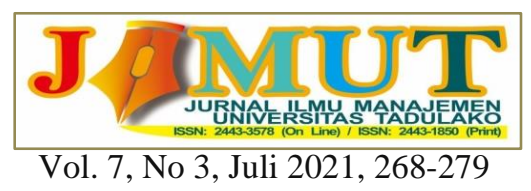

sumber dana baik jangka pendek maupun jangka panjang. Sumber dana tersebut akan digunakan dalam perusahaan sebagai sumber pembiayaan serta kegiatan penunjang operasional sehari-hari.

Sumber dana merupakan pos-pos yang akan menaikkan jumlah uang kas dan modal kerja sedangkan penggunaan dana merupakan pos-pos yang akan menurunkan uang kas dan modal kerja. Pengelolaan dana dalam perusahaan harus memenuhi kebutuhan perusahaan, karena dana sangat dibutuhkan oleh perusahaan dalam menggerakkan usahanya. Biasanya dana diperlukan untuk dua hal, yaitu untuk mendanai kegiatan sehari-hari perusahaan dan akan mengadakan penanaman modal dalam aktiva tetap. Pertama, pengeluaran dana untuk membiayai operasi perusahaan sehari-hari dapat bersifat terus-menerus digunakan untuk pembiayaan jangka pendek, misalnya pembelian bahan baku atau mentah, pembayaran upah atau gaji buruh, dan biaya operasional lainnya. Kedua, pengeluaran dana dalam hal untuk mengadakan investasi baru artinya digunakan untuk membeli dan membiayai aktivitas aktiva tetap dan bersifat jangka panjang yang dapat digunakan berulang-ulang, misalnya pembelian tanah, bangunan, mesin, kendaraan, dan aktiva tetap lainnya.

Usaha untuk memperoleh dana berkaitan dengan aliran dana yang masuk sebagai sumber dana, sedangkan aliran kas keluar berkaitan dengan penggunaan dana. Aliran atau arus dana yang ada di perusahaan harus dikelola secara profesional untuk menjaga likuiditas perusahaan. Perencanaan aliran dana yang baik membawa perusahaan dalam kondisi yang sehat. Aliran dana di perusahaan juga harus dikelola keseimbangannya antara dana yang masuk dengan dana yang keluar. Keseimbangan ini juga berdampak pada stabilitas operasi perusahaan. Kelebihan dana di perusahaan dapat berakibat penggunaan dana yang kurang efisien, sebaliknya kekurangan dana akan mengakibatkan terganggunya operasi perusahaan.

Aliran dana yang terjadi di perusahaan bersifat terus menerus dan tidak. Aliran dana yang bersifat terus menerus biasanya terjadi untuk kegiatan atau operasi perusahaan sehari-hari sementara aliran dana yang tidak kontinyu biasanya untuk kegiatan yang terjadi secara insidentil. Aliran dana masuk (sumber dana) dan aliran dana keluar (penggunaan dana) di perusahaan dapat dibagi menjadi 2 istilah yaitu dana dalam pengertian kas dan dana dalam pengertian modal kerja.

Analisis sumber dan penggunaan dana, atau sering juga disebut dengan analisa aliran dana, adalah merupakan alat analisa finansial yang sangat berperan penting bagi finansial manajer. Maksud utama dari analisa ini adalah untuk mengetahui bagaimana dana digunakan dan bagaimana kebutuhan dana tersebut dibelanjai, dengan kata lain analisa laporan dana yaitu darimana datangnya dana dan untuk apa dana digunakan. Suatu laporan yang menggambarkan darimana datangnya dana dan untuk apa dana digunakan disebut laporan sumber dan penggunaan dana. Pengertian dana yang digunakan dalam analisa sumber dan penggunaan dana tersebut dalam artian sempit dapat diartikan sebagai "kas" atau dalam artian luas disebut "modal kerja" (Riyanto, 2011:346).

Untuk menyusun laporan sumber dan penggunaan dana, langkah pertama yang harus dilakukan adalah membuat Laporan Perubahan Neraca yang disusun dari neraca dua tahun berurutan. Laporan ini menggambarkan perubahan dari masing-masing elemen neraca dari neraca awal menjadi neraca akhir. Perubahan dari masing-masing elemen tersebut perlu dilakukan analisis, yaitu elemen-elemen mana saja yang memperbesar dana menjadi sumber dana dan elemen yang memperkecil dana akan menjadi penggunaan dana.

Sumber-sumber dana dalam artian kas terdiri dari: (1) Berkurangnya aktiva lancar selain kas, (2) Berkurangnya aktiva tetap, (3) Bertambahnya setiap jenis utang, (4) Bertambahnya modal, (5) Adanya keuntungan dari operasi perusahaan, dan (6) Penyusutan. Sedangkan penggunaan dana dalam artian kas adalah terdiri dari: (1) Bertambahnya aktiva lancar selain kas, (2) Bertambahnya 
aktiva tetap, (3) Berkurangnya setiap jenis utang, (4) Berkurangnya modal, (5) Pembayaran cash dividen, dan (6) Adanya kerugian operasional perusahaan.

Dana dalam artian modal kerja dalam laporan sumber dan penggunaan dana modal kerja tidak tercantum didalamnya sumber-sumber dari penggunaan dana berasal dari unsur-unsur modal kerja sendiri, karena perubahan-perubahan hanya menyangkut unsur-unsur akiva lancar dan utang lancar saja. Kedua accounts tersebut disebut current accounts tidak akan mengakibatkan terjadinya perubahan pada modal kerja (netto).

Dengan demikian maka jumlah modal kerja hanya akan berubah jika ada perubahan unsurunsur Non-Current Account (aktiva tetap, utang jangka panjang dan modal sendiri). Yang mempunyai efek memperbesar modal disebut sebagai sumber modal kerja. Sedangkan yang mempunyai efek mengurangi modal kerja disebut sebagai penggunaan modal kerja.

Apabila sumber lebih besar daripada penggunaan, berarti mempunyai efek positif terhadap modal kerja yaitu akan menambah modal kerja, sebaliknya jika penggunaan lebih besar daripada sumber, maka efeknya adalah memperkecil modal kerja. Dan jika sumber sama dengan penggunaan, maka tidak ada efek terhadap modal kerja, artinya modal kerja tidak berubah.

Demikian halnya dengan PT. Bumi Sarana Utama Cabang Palu dalam menjalankan usahanya sebagai agen aspal curah di Kota Palu, perlu memperhatikan sumber dan penggunaan dana. Gambaran tentang sumber dan penggunaan dana pada PT. Bumi Sarana Utama Cabang Palu untuk periode tahun 2016 - 2018 disajikan pada gambar di bawah ini:

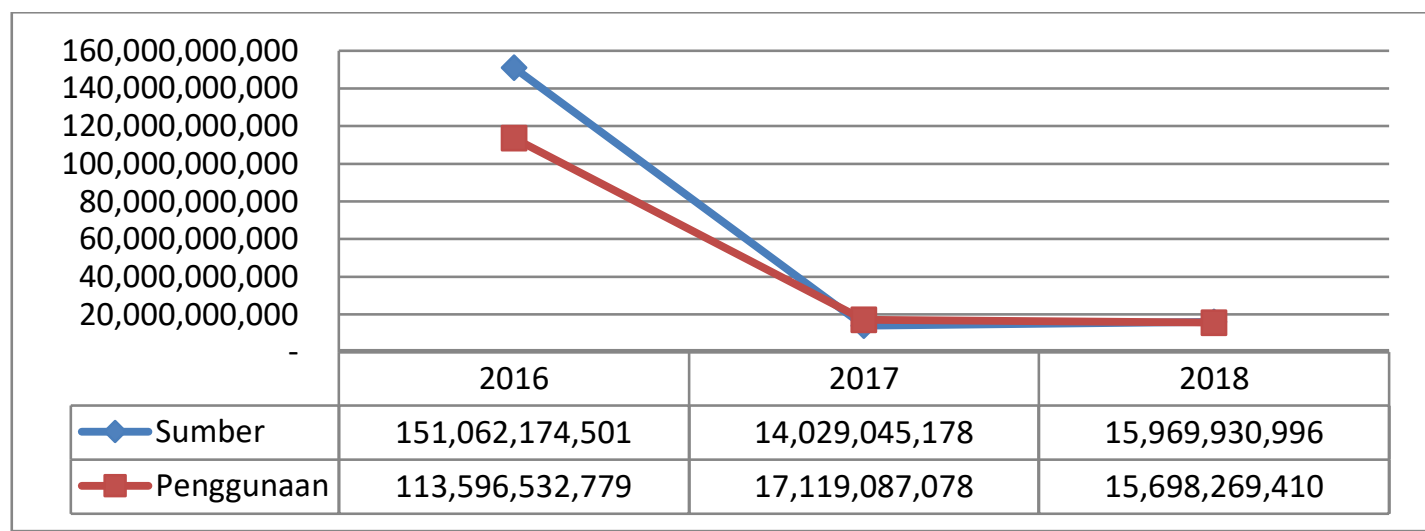

Gambar 1.1. Sumber dan Penggunaan Dana PT. Bumi Sarana Utama Cabang Palu Periode Tahun 2016 - 2018 (Dalam Jutaan Rupiah)

Gambar di atas menunjukkan bahwa pada tahun 2017 terjadi kelebihan penggunaan dana dibandingkan sumber dana yang dikelola oleh PT. Bumi Sarana Utama Cabang Palu. Kondisi ini dapat mempengaruhi kondisi keuangan perusahaan dan berdampak pada operasional perusahaan secara menyeluruh.

\section{KAJIAN LITERATUR}

Dana

Indriyo (2007:27) mengatakan bahwa dana adalah merupakan kekayaan atau aktiva yang diperlukan oleh perusahaan untuk melakukan kegiatan sehari-hari dan yang selalu berputar.

\section{Analisis Sumber dan Penggunaan Dana}

Pengertian dana yang digunakan dalam analisis sumber dan penggunaan dana perusahaan dalam artian sempit diartikan sebagai Kas. Sedangkan dalam artian luas diartikan sebagai Modal Kerja. Hasil penggunaan sumber-sumber dana, tidak semata-mata sebatas menentukan tingkat 


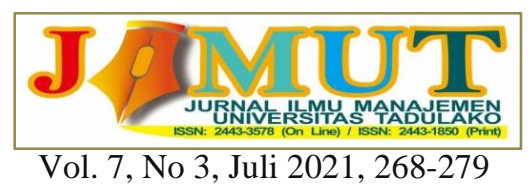

profitabilitas tapi turut pula menentukan kontinuitas perusahaan. Menurut Munawir (2009:110), Analisis sumber dan penggunaan dana merupakan suatu alat analisis keuangan yang sangat penting bagi finansial manajer atau bagi para calon kreditur atau bagian bank dalam menilai permintaan kredit yang diajukan kepadanya, dengan analisa sumber dan penggunaan dana maka akan diketahui bagaimana perusahaan mengelola atau menggunakan dana yang dimilikinya".

\section{Dana Dalam Arti Kas}

Dana dalam artian kas, artinya setiap ada perubahan elemen-elemen yang ada pada laporan keuangan akan menambah atau mengurangi kas. Oleh karena itu, laporannya disebut sebagai Laporan Sumber dan Penggunaan Kas. Laporan sumber dan penggunaan kas disusun untuk menunjukkan perubahan kas selama satu periode dan memberikan alasan mengenai perubahan kas tersebut dengan cara menunjukkan darimana sumber-sumber kas dan pengunaan-penggunaannya.

\section{Dana Dalam Arti Modal Kerja}

Dalam kenyataannya selain membuat laporan sumber dan penggunaan dana atas dasar kas, perusahaan juga membuat laporan sumber dan penggunaan dana atas dasar modal kerja (statements of sources and uses of working capital). Modal kerja dapat diartikan beberapa Modal kerja adalah kelebihan aktiva lancar diatas hutang lancar. Dalam laporan sumber dan penggunaan modal kerja tidak dicantumkan penggunaan dana yang berasal dari modal sendiri karena tidak akan mengakibatkan perubahan modal kerja (netto).

\section{METODE PENELITIAN}

\section{Jenis Penelitian}

Sesuai tingkat eksplanasi, penelitian ini dikategorikan ke dalam jenis penelitian deskriptif. Penelitian deskriptif dalam penelitian ini dimaksudkan untuk memberikan gambaran tentang analisis sumber dan penggunaan dana pada PT. Bumi Sarana Utama Cabang Palu melalui data-data perusahaan selama periode tahun 2016 sampai dengan 2018.

\section{Lokasi Penelitian}

Penelitian ini dilakukan pada PT. Bumi Sarana Utama Cabang Palu dengan suatu dasar pertimbangan bahwa belum pernah ada penelitian sebelumnya pada perusahaan yang diteliti meneliti tentang sumber dan penggunaan dana sehingga orisinalitas penelitian ini secara moralitas dapat dipertanggungjawabkan.

\section{Jenis dan Sumber Data}

Data yang dikumpulkan adalah berupa data sekunder, yaitu jenis data yang diperoleh secara langsung dari PT. Bumi Sarana Utama Cabang Palu berupa data tentang laporan keuangan perusahaan yang berhubungan dengan sumber dan penggunaan dana perusahaan (Neraca dan Laporan Laba-Rugi).

\section{Teknik Pengambilan dan Pengumpulan Data}

Untuk memperoleh data yang jelas dan akurat maka dalam penelitian ini penulis menggunakan teknik pengambilan dan pengumpulan data dengan cara wawancara, pengamatan dan dokumentasi.

\section{Teknik Analisis Data}

Untuk memecahkan rumusan masalah pertama dalam penelitian ini yaitu bagaimana kebijakan sumber dan penggunaan dana pada PT. Bumi Sarana Utama Cabang Palu dari tahun 2016 sampai dengan tahun 2018, maka digunakan langkah-langkah sebagai berikut: 
Kebijakan sumber dan penggunaan dana dalam arti kas pada PT. Bumi Sarana Utama Cabang Palu dari tahun 2016 sampai dengan tahun 2018, langkah-langkahnya adalah sebagai berikut (Riyanto, 2014:288):

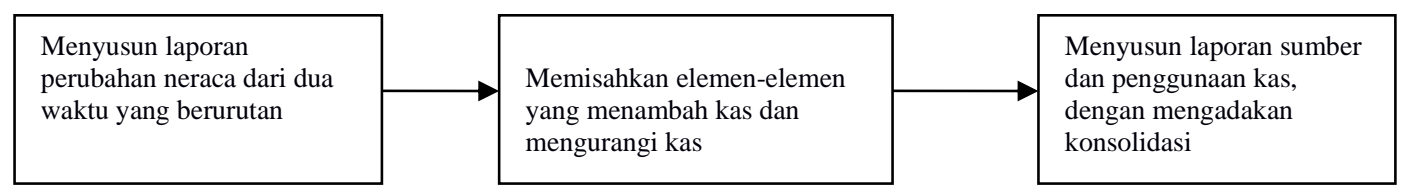

Gambar 3.1. Analisis Kebijakan Sumber dan Penggunaan Dana Kas

Kebijakan sumber dan penggunaan dana dalam arti modal kerja pada PT. Bumi Sarana Utama Cabang Palu dari tahun 2016 sampai dengan tahun 2018, langkah-langkahnya adalah sebagai berikut (Riyanto, 2014:294):

\begin{tabular}{|l|l|l|l|l|l}
\hline $\begin{array}{l}\text { Menyusun Laporan } \\
\text { Perubahan Modal Kerja }\end{array} \longrightarrow$ & $\begin{array}{l}\text { Mengelompokkan elemen-elemen } \\
\text { neraca dan laporan rugi-laba yang } \\
\text { memperbesar dan memperkecil } \\
\text { modal kerja }\end{array}$
\end{tabular}$\longrightarrow$\begin{tabular}{l}
$\begin{array}{l}\text { Menyun laporan sumber-sumber } \\
\text { dan penggunaan modal kerja } \\
\text { dengan mengkonsolidasikan } \\
\text { perubahan-perubahannya }\end{array}$ \\
\hline
\end{tabular}

Gambar 3.2. Analisis Kebijakan Sumber dan Penggunaan Dana Modal Kerja

\section{HASIL DAN PEMBAHASAN}

Sumber dan Penggunaan Kas Periode Tahun 2016

Berdasarkan pada Laporan Perubahan Neraca PT. Bumi Sarana Utama Cabang Palu periode 31 Desember 2016 dan 31 Desember 2015, maka dapat diketahui perubahan setiap akun-akunnya sebagaimana terlihat pada Laporan Sumber dan Penggunaan Kas pada Tabel 5.1. berikut ini:

Tabel 5.1.

Laporan Sumber dan Penggunaan Kas PT. Bumi Sarana Utama Cabang Palu Periode 31 Desember 2016

\begin{tabular}{|c|c|c|c|c|}
\hline NO & SUMBER KAS & $\begin{array}{l}\text { JUMLAH } \\
\text { (RP) }\end{array}$ & PENGGUNAAN KAS & $\begin{array}{l}\text { JUMLAH } \\
\text { (RP) }\end{array}$ \\
\hline 1 & Bank & $34,456,304,382$ & $\begin{array}{l}\text { Bertambahnya Piutang } \\
\text { Afiliasi }\end{array}$ & $79,991,785,043$ \\
\hline 2 & Berkurangnya Piutang Usaha & $28,318,870,000$ & $\begin{array}{l}\text { Bertambahnya Biaya Dibayar } \\
\text { Dimuka }\end{array}$ & $7,379,061$ \\
\hline 3 & Berkurangnya Piutang Karyawan & $11,347,851$ & Bertambahnya Aktiva Tetap & $248,034,645$ \\
\hline 4 & Berkurangnya Persediaan & $11,073,014,365$ & Berkurangnya Hutang Bank & $28,500,000,000$ \\
\hline 5 & $\begin{array}{l}\text { Bertambahnya Kewajiban Manfaat } \\
\text { Kes Kary }\end{array}$ & $400,000,000$ & Berkurangnya Hutang Pajak & $3,366,488,402$ \\
\hline 6 & Bertambahnya Ekuitas & $38,401,318,951$ & $\begin{array}{l}\text { Berkurangnya Biaya YMH } \\
\text { Dibayar }\end{array}$ & $1,482,845,628$ \\
\hline \multirow[t]{4}{*}{7} & Laba Operasi Perusahaan & $38,401,318,952$ & & \\
\hline & TOTAL & $151,062,174,501$ & TOTAL & $113,596,532,779$ \\
\hline & & & KENAIKAN KAS & $37,465,641,722$ \\
\hline & TOTAL KESEIMBANGAN & $151,062,174,501$ & $\begin{array}{c}\text { TOTAL } \\
\text { KESEIMBANGAN }\end{array}$ & $151,062,174,501$ \\
\hline
\end{tabular}

Sumber: Data Sekunder diolah kembali, 2019.

Berdasarkan laporan sumber dan penggunaan kas pada PT. Bumi Sarana Utama Cabang Palu periode 31 Desember 2016 tersebut di atas, terlihat bahwa jumlah kas (sumber kas) adalah sebesar 
Rp.151.062.174.501,-, sedangkan untuk pengeluaran kas selama tahun 2016 adalah Rp.113.596.532.779,-. Karena sumber kas lebih besar dari penggunaan kas, maka menyebabkan nilai kas bertambah atau terjadi kenaikan kas sebesar Rp.37.465.641.722,-. Peningkatan kas ini terjadi karena adanya penggunaan kas yang lebih kecil dari sumber kas yang dimiliki perusahaan, sehingga di nilai struktur pembiayaan atau pembelanjaan yang dilakukan oleh PT. Bumi Sarana Utama Cabang Palu sudah tepat, karena dari pandangan likuiditas tidak ada kebutuhan dana jangka panjang yang dibelanjai dengan sumber dana jangka pendek dan kebutuhan dana jangka pendek dipenuhi dengan sumber dana jangka pendek.

\section{Sumber dan Penggunaan Kas Periode Tahun 2017}

Berdasarkan pada Laporan Perubahan Neraca PT. Bumi Sarana Utama Cabang Palu periode 31 Desember 2017 dan 31 Desember 2016, maka dapat dilihat perubahan setiap akun-akunnya sebagaimana terlihat pada Laporan Sumber dan Penggunaan Kas pada Tabel 5.2. berikut ini:

Tabel 5.2.

Laporan Sumber dan Penggunaan Kas PT. Bumi Sarana Utama Cabang Palu

Periode 31 Desember 2017

\begin{tabular}{|c|c|c|c|c|}
\hline NO & SUMBER KAS & $\begin{array}{l}\text { JUMLAH } \\
\text { (RP) }\end{array}$ & PENGGUNAAN KAS & $\begin{array}{l}\text { JUMLAH } \\
\text { (RP) }\end{array}$ \\
\hline 1 & Berkurangnya Piutang Afiliasi & $3,329,844,218$ & Bank & $2,323,941,695$ \\
\hline 2 & Berkurangnya Piutang Karyawan & $11,275,000$ & Bertambahnya Piutang Usaha & $7,382,820,000$ \\
\hline 3 & Bertambahnya Hutang Bank & $5,000,000,000$ & Bertambahnya Persediaan & $4,185,891,830$ \\
\hline 4 & Bertambahnya Hutang Lain-Lain & $3,236,563$ & $\begin{array}{l}\text { Bertambahnya Biaya Dibayar } \\
\text { Dimuka }\end{array}$ & $25,842,094$ \\
\hline 5 & $\begin{array}{l}\text { Bertambahnya Kewajiban } \\
\text { Manfaat Kes Kary }\end{array}$ & $275,000,000$ & Bertambahnya Aktiva Tetap & $678,399,746$ \\
\hline 6 & Bertambahnya Ekuitas & $4,497,711,637$ & Berkurangnya Hutang Pajak & $1,771,991,804$ \\
\hline \multirow[t]{4}{*}{7} & Laba Operasi Perusahaan & $911,977,760$ & $\begin{array}{l}\text { Berkurangnya Biaya YMH } \\
\text { Dibayar }\end{array}$ & $750,199,909$ \\
\hline & TOTAL & $14,029,045,178$ & TOTAL & $\mathbf{1 7 , 1 1 9 , 0 8 7 , 0 7 8}$ \\
\hline & PENURUNAN KAS & $3,090,041,900$ & & \\
\hline & TOTAL KESEIMBANGAN & $17,119,087,078$ & TOTAL KESEIMBANGAN & $17,119,087,078$ \\
\hline
\end{tabular}

Sumber: Data Sekunder diolah kembali, 2019.

Berdasarkan laporan sumber dan penggunaan kas pada PT. Bumi Sarana Utama Cabang Palu periode 31 Desember 2017 tersebut di atas, terlihat bahwa jumlah kas (sumber kas) adalah sebesar Rp.14.029.045.178,-, sedangkan untuk pengeluaran kas selama tahun 2017 adalah Rp.17.119.087.078,-. Karena sumber kas lebih kecil dari penggunaan kas, maka menyebabkan nilai kas berkurang atau terjadi penurunan kas sebesar Rp.3.090.041.900,-. Penurunan kas terjadi karena adanya penggunaan kas yang lebih besar dari sumber kas dimiliki perusahaan. Sehingga dinilai struktur pembiayaan atau pembelanjaan yang dilakukan PT. Bumi Sarana Utama Palu dinilai kurang tepat, karena pada pandangan likuiditas penggunaan kas yang melebihi sumber kas telah menandakan adanya sebagian kebutuhan dana jangka panjang yang dibelanjai dengan sumber dana jangka pendek.

\section{Sumber dan Penggunaan Kas Periode Tahun 2018}




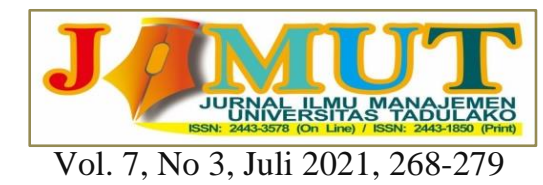

Berdasarkan pada Laporan Perubahan Neraca PT. Bumi Sarana Utama Cabang Palu periode 31 Desember 2018 dan 31 Desember 2017, maka dapat dilihat perubahan setiap akun-akunnya sebagaimana terlihat pada Laporan Sumber dan Penggunaan Kas pada Tabel 5.3. berikut ini:

Tabel 5.3.

Laporan Sumber dan Penggunaan Kas PT. Bumi Sarana Utama Cabang Palu

Periode 31 Desember 2018

\begin{tabular}{|c|c|c|c|c|}
\hline NO. & SUMBER KAS & $\begin{array}{l}\text { JUMLAH } \\
\text { (RP) }\end{array}$ & PENGGUNAAN KAS & $\begin{array}{l}\text { JUMLAH } \\
\text { (RP) }\end{array}$ \\
\hline 1 & Bank & $7,422,944,963$ & Bertambahnya Piutang Usaha & $4,819,179,900$ \\
\hline 2 & $\begin{array}{l}\text { Berkurangnya Piutang } \\
\text { Afiliasi }\end{array}$ & $121,936,338$ & Bertambahnya Persediaan & $5,778,601,142$ \\
\hline 3 & $\begin{array}{l}\text { Berkurangnya Piutang } \\
\text { Karyawan }\end{array}$ & $18,450,000$ & $\begin{array}{l}\text { Bertambahnya Pajak Dibayar } \\
\text { Dimuka }\end{array}$ & $211,556,008$ \\
\hline 4 & $\begin{array}{l}\text { Berkurangnya Biaya Dibayar } \\
\text { Dimuka }\end{array}$ & $22,013,352$ & Berkurangnya Hutang Pajak & $544,848,080$ \\
\hline 5 & Berkurangnya Aktiva Tetap & $905,107,087$ & $\begin{array}{l}\text { Berkurangnya Biaya YMH } \\
\text { Dibayar }\end{array}$ & $4,337,778,077$ \\
\hline 6 & Bertambahnya Hutang Usaha & $1,242,127,658$ & $\begin{array}{l}\text { Berkurangnya Hutang Lain- } \\
\text { Lain }\end{array}$ & $6,306,203$ \\
\hline 7 & Bertambahnya Ekuitas & $5,953,533,555$ & & \\
\hline \multirow[t]{4}{*}{8} & Laba Operasi Perusahaan & $283,818,043$ & & \\
\hline & TOTAL & $15,969,930,996$ & TOTAL & $15,698,269,410$ \\
\hline & & & KENAIKAN KAS & $271,661,586$ \\
\hline & $\begin{array}{c}\text { TOTAL } \\
\text { KESEIMBANGAN }\end{array}$ & $15,969,930,996$ & TOTAL KESEIMBANGAN & $15,969,930,996$ \\
\hline
\end{tabular}

Sumber: Data Sekunder diolah kembali, 2019.

Berdasarkan laporan sumber dan penggunaan kas pada PT. Bumi Sarana Utama Cabang Palu periode 31 Desember 2018 tersebut di atas, terlihat bahwa jumlah kas (sumber kas) adalah sebesar Rp.15.969.930.996,-, sedangkan untuk pengeluaran kas selama tahun 2018 adalah Rp.15.698.269.410,-. Karena sumber kas lebih besar dari penggunaan kas, maka menyebabkan nilai kas bertambah atau terjadi kenaikan kas sebesar Rp.271.661.586,-. Kelebihan kas ini terjadi karena adanya sumber kas yang diperoleh oleh PT. Bumi Sarana Utama Palu periode 31 Desember 2018 lebih besar dari yang diperlukan atau lebih besar daripada penggunaan kas. sehingga di nilai struktur pembiayaan atau pembelanjaan yang dilakukan oleh PT. Bumi Sarana Utama Palu sudah tepat, karena dari pandangan likuiditas tidak ada kebutuhan dana jangka panjang yang dibelanjai dengan sumber dana jangka pendek dan kebutuhan dana jangka pendek dipenuhi dengan sumber dana jangka pendek.

Dengan demikian manajemen penerimaan dan pengelolaan kas yang dilakukan oleh pihak perusahaan sudah baik, ditandai dengan cadangan kas yang ada pada perusahaan dinilai mencukupi 


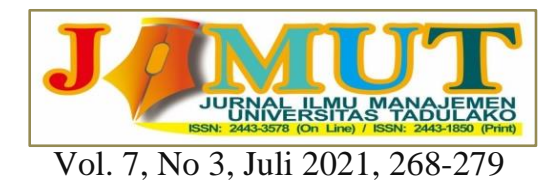

untuk memenuhi kewajiban jangka pendek perusahaan yang berdampak kepada terjaganya kepercayaan pihak luar terhadap perusahaan.

\section{Sumber dan Penggunaan Modal Kerja Periode Tahun 2016}

Berdasarkan pada Laporan Perubahan Neraca PT. Bumi Sarana Utama Caang Palu periode 31 Desember 2016 dan 31 Desember 2015, maka dapat dilihat perubahan setiap akun-akunnya sebagaimana terlihat pada Laporan Sumber dan Penggunaan Modal Kerja pada Tabel 5.4. berikut ini:

Tabel 5.4.

Laporan Sumber dan Penggunaan Modal Kerja PT. Bumi Sarana Utama Cabang Palu

Periode 31 Desember 2016

\begin{tabular}{|c|l|r|r|r|}
\hline NO. & \multicolumn{1}{|c|}{$\begin{array}{c}\text { SUMBER MODAL } \\
\text { KERJA }\end{array}$} & $\begin{array}{c}\text { JUMLAH } \\
(\text { RP) }\end{array}$ & $\begin{array}{c}\text { PENGGUNAAN } \\
\text { MODAL KERJA }\end{array}$ & $\begin{array}{c}\text { JUMLAH } \\
(\text { RP) }\end{array}$ \\
\hline 1 & $\begin{array}{l}\text { Bertambahnya Hutang Tidak } \\
\text { Lancar }\end{array}$ & $400,000,000$ & Bertambahnya Aktiva Tetap & $248,034,645$ \\
\hline 2 & $\begin{array}{l}\text { Bertambahnya Ekuitas } \\
\text { (Modal) }\end{array}$ & $38,401,318,951$ & & \\
\hline 3 & $\begin{array}{l}\text { Keuntungan Operasi } \\
\text { Perusahaan }\end{array}$ & $117,127,609$ & & \\
\hline 4 & Akumulasi Biaya Penyusutan & $1,104,212,389$ & & $\mathbf{2 4 8 , 0 3 4 , 6 4 5}$ \\
\hline \multicolumn{2}{|c|}{ TOTAL } & $\mathbf{4 0 , 0 2 2 , 6 5 8 , 9 4 9}$ & TOTAL & $\mathbf{3 9 , 7 7 4 , 6 2 4 , 3 0 4}$ \\
\hline & \multicolumn{3}{|c|}{ KENAIKAN MODAL KERJA } & $\mathbf{4 0 , 0 2 2 , 6 5 8 , 9 4 9}$ \\
\hline
\end{tabular}

Sumber: Data Sekunder diolah kembali, 2019.

Dari Tabel 5.4. di atas, maka dapat diketahui pada tahun 2016 PT. Bumi Sarana Utama Cabang Palu mengalami kenaikan modal kerja sebesar Rp.39.774.624.304,- dimana kenaikan modal kerja tertinggi bersumber dari komponen bertambahnya ekuitas (modal) dengan nilai Rp.38.401.318.951,-, Kenaikan modal kerja ini disebabkan karena sumber modal kerja lebih besar daripada penggunaannya. Selanjutnya penggunaan modal kerja pada PT. Bumi Sarana Utama Cabang Palu untuk periode tahun 2016 berasal dari komponen akun bertambahnya aktiva tetap dengan nilai sebesar Rp.248.034.645,-.

\section{Sumber dan Penggunaan Modal Kerja Periode Tahun 2017}

Berdasarkan pada Laporan Perubahan Neraca PT. Bumi Sarana Utama Cabang Palu periode 31 Desember 2017 dan 31 Desember 2016, maka dapat dilihat perubahan setiap akun-akunnya sebagaimana terlihat pada Laporan Sumber dan Penggunaan Modal Kerja pada Tabel 5.5. berikut ini:

Tabel 5.5.

Laporan Sumber dan Penggunaan Modal Kerja PT. Bumi Sarana Utama Cabang Palu

Periode 31 Desember 2017

\begin{tabular}{|c|l|c|c|c|}
\hline NO & SUMBER MODAL KERJA & $\begin{array}{c}\text { JUMLAH } \\
(\text { RP })\end{array}$ & $\begin{array}{c}\text { PENGGUNAAN } \\
\text { MODAL KERJA }\end{array}$ & $\begin{array}{c}\text { JUMLAH } \\
\text { (RP) }\end{array}$ \\
\hline 1 & $\begin{array}{l}\text { Bertambahnya Hutang Jangka } \\
\text { Panjang }\end{array}$ & $275,000,000$ & Bertambahnya Aktiva Tetap & $678,399,746$ \\
\hline
\end{tabular}




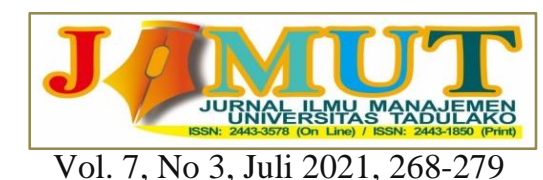

\begin{tabular}{|c|c|c|c|c|}
\hline 2 & Bertambahnya Modal (Ekuitas) & $4,497,711,637$ & & \\
\hline 3 & Keuntungan Operasi Perusahaan & $911,977,760$ & & \\
\hline 4 & Akumulasi Biaya Penyusutan & $1,055,469,415$ & & \\
\hline & TOTAL & $6,740,158,812$ & TOTAL & $678,399,746$ \\
\hline & \multicolumn{3}{|c|}{ KENAIKAN MODAL KERJA } & $6,061,759,066$ \\
\hline & TOTAL KESEIMBANGAN & $6,740,158,812$ & $\begin{array}{c}\text { TOTAL } \\
\text { KESEIMBANGAN }\end{array}$ & $6,740,158,812$ \\
\hline
\end{tabular}

Sumber: Data Sekunder diolah kembali, 2019.

Dari Tabel 5.5. di atas, dapat diketahui pada tahun 2017 PT. Bumi Sarana Utama Cabang Palu mengalami kenaikan modal kerja sebesar Rp.6.061.759.066,- dimana kenaikan modal kerja ini sangat berdampak positif pada perusahaan karena dapat mempertahankan kenaikan modal kerja pada tahun sebelumnya. Kenaikan modal kerja ini dikarenakan sumber modal kerja lebih besar daripada penggunaannya, sumber modal kerja pada PT. Bumi Sarana Utama Cabang Palu periode tahun 2017 yang paling besar bersumber dari akun komponen bertambahnya ekuitas (modal) dengan nilai sebesar Rp.4.497.711.637,-. Selanjutnya penggunaan modal kerja pada PT. Bumi Sarana Utama Cabang Palu untuk periode tahun 2016 berasal dari komponen akun bertambahnya aktiva tetap dengan nilai Rp.678.399.746,--.

\section{Sumber dan Penggunaan Modal Kerja Periode Tahun 2018}

Berdasarkan pada Laporan Neraca Perbandingan PT. Bumi Sarana Utama Cabang Palu periode 31 Desember 2017 dan 31 Desember 2018, maka dapat dilihat perubahan setiap akun-akun modal kerja sebagaimana terlihat pada Laporan Sumber dan Penggunaan Modal Kerja. pada Tabel 5.6. berikut ini:

Tabel 5.6.

Laporan Sumber dan Penggunaan Modal Kerja PT. Bumi Sarana Utama Cabang Palu Periode 31 Desember 2018

\begin{tabular}{|c|l|c|c|c|}
\hline NO & \multicolumn{1}{|c|}{$\begin{array}{c}\text { SUMBER MODAL } \\
\text { KERJA }\end{array}$} & $\begin{array}{c}\text { JUMLAH } \\
(\text { RP) }\end{array}$ & $\begin{array}{c}\text { PENGGUNAAN MODAL } \\
\text { KERJA }\end{array}$ & $\begin{array}{c}\text { JUMLAH } \\
\text { (RP) }\end{array}$ \\
\hline 1 & Berkurangnya Aktiva Tetap & $905,107,087$ & & - \\
\hline 2 & Bertambahnya Modal (Ekuitas) & $5,953,533,555$ & & \\
\hline 3 & $\begin{array}{l}\text { Keuntungan Operasi } \\
\text { Perusahaan }\end{array}$ & $283,818,043$ & & \\
\hline 4 & Akumulasi Biaya Penyusutan & $1,009,040,695$ & & \\
\hline & \multicolumn{1}{|c|}{ TOTAL } & $\mathbf{8 , 1 5 1 , 4 9 9 , 3 8 0}$ & TOTAL & - \\
\hline
\end{tabular}

Sumber: Data Sekunder diolah kembali, 2019.

Dari Tabel 5.6. di atas, maka dapat diketahui pada tahun 2018 PT. Bumi Sarana Utama Cabang Palu kembali mengalami kenaikan modal kerja dengan nilai sebesar Rp.8.151.499.380,dimana kenaikan modal kerja ini memberikan dampak positif pada perusahaan karena 2 (dua) tahun sebelumnya yaitu pada periode tahun 2016 dan 2017 perusahaan juga mengalami kenaikan modal kerja. Kenaikan modal kerja ini dikarenakan pada periode tahun 2018 sumber modal kerja pada PT. Bumi Sarana Utama Cabang Palu melebihi penggunaan modal kerjanya, dimana sumber 


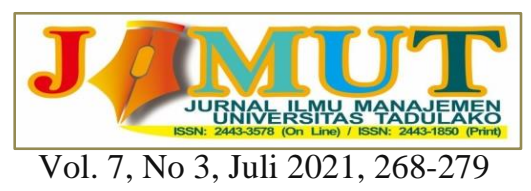

modal kerja tertinggi berasal dari akun komponen bertambahnya modal (ekuitas) dengan nilai sebesar Rp.5.953.533.555,-. Kenaikan modal kerja perusahaan pada periode tahun 2018 ini disebabkan sumber modal kerja perusahaan melebihi daripada penggunaannya.

Berdasarkan pada hasil analisis sumber dan penggunaan modal kerja pada PT. Bumi Sarana Utama Cabang Palu periode tahun 2016 - 2018 di atas, maka penulis dapat menggambarkan bahwa selama periode tahun 2016 - 2018 perusahaan mengalami kenaikan modal kerja. Sumber dan modal utama perusahaan berasal dari komponen bertambahnya ekuitas perusahaan dalam setiap tahunnya yang dapat digunakan untuk membeli aset tetap, renovasi bangunan sewa, dan aset tidak lancar lainnya. Hasil dari analisis ini menggambarkan analisis sumber dan penggunaan modal kerja pada PT. Bumi Sarana Utama Cabang Palu periode tahun 2016 - 2018 sudah efisien. Modal kerja mengalami kenaikan setiap tahunnya begitu juga dengan laba yang didapatkan melalui operasional perusahaan dapat dipertahankan dalam setiap tahunnya. Hal ini menandakan kebijakan sumber modal kerja perusahaan sudah optimal dalam arti pencarian sumber modal kerja yang merupakan tulang punggung operasional perusahaan selalu tersedia dan mengalami kenaikan, sehingga kebijakan perusahaan khususnya yang sangat berkaitan dengan operasionalisasi guna mendapatkan laba yang optimal dapat dicapai. Begitupun dengan kebijakan penggunaan modal kerja dapat dikatakan telah sesuai dengan sasaran manajemen perusahaan khususnya dalam bidang keuangan menyangkut berjalannya operasionalisasi perusahaan.

\section{KESIMPULAN DAN SARAN}

\section{Kesimpulan}

Berdasarkan pada hasil penelitian dan pembahasan, maka dalam penelitian ini penulis dapat menarik beberapa kesimpulan sebagai berikut:

1. Hasil analisis sumber dan penggunaan kas pada pada PT. Bumi Sarana Utama Cabang Palu periode tahun 2016-2018, menggambarkan bahwa sumber kas yang diperoleh perusahaan lebih besar daripada penggunaan kas perusahaan sehingga di nilai struktur pembiayaan atau pembelanjaan yang dilakukan oleh perusahaan sudah tepat, karena dari pandangan likuiditas tidak ada kebutuhan dana jangka panjang yang dibelanjai dengan sumber dana jangka pendek dan kebutuhan dana jangka pendek dipenuhi dengan sumber dana jangka pendek. Sehingga dengan demikian manajemen penerimaan dan pengelolaan kas telah dilakukan oleh pihak perusahaan dengan baik, ditandai dengan cadangan kas yang ada pada perusahaan dinilai mencukupi untuk memenuhi kewajiban jangka pendek perusahaan yang memberikan dampak terjaganya kepercayaan pihak luar terhadap perusahaan.

2. Hasil analisis sumber dan penggunaan modal kerja pada PT. Bumi Sarana Utama Cabang Palu periode tahun 2016-2018, menggambarkan bahwa sumber dan penggunaan modal kerja sudah efisien, dimana modal kerja mengalami kenaikan setiap tahunnya begitu juga dengan laba yang didapatkan melalui operasional perusahaan dapat dipertahankan dalam setiap tahunnya. Hal ini menandakan sumber modal kerja perusahaan senantiasa tersedia dan mengalami kenaikan, sehingga kebijakan perusahaan yang berkaitan dengan operasionalisasi usaha guna mendapatkan laba yang optimal dapat dicapai. Begitupun dengan kebijakan penggunaan modal kerja telah sesuai dengan sasaran manajemen perusahaan dalam bidang keuangan menyangkut berjalannya operasionalisasi perusahaan.

\section{Saran}

Beberapa hal yang dapat penulis sarankan kepada pihak-pihak berkompeten berkaitan dengan analisis sumber dan penggunaan dana pada PT. Bumi Sarana Utama Cabang Palu adalah sebagai berikut: 


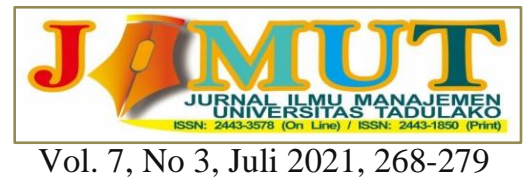

1. PT. Bumi Sarana Utama Cabang Palu diharapkan berhati-hati dalam memilih dan menggunakan sumber-sumber dana jangka pendek (aktiva lancar) seperti kas, pinjaman bank, piutang dan persediaan untuk digunakan mendanai investasi jangka panjang perusahaan dalam rangka memperluas usaha perusahaan, agar penggunaan dana perusahaan tepat.

2. Diharapkan manajemen PT. Bumi Sarana Utama Cabang Palu lebih berorientasi kepada kebijakan sumber dan penggunaan dana (kas dan modal kerja) dalam arti meningkatkan penerimaan kas dan modal kerja serta efisien dan efektif dalam menggunakan kas dan modal kerja agar tujuan perusahaan dapat tercapai yaitu mengoptimalkan laba untuk tujuan dalam jangka pendek dan menjaga kontinuitas (keberlangsungan) perusahaan untuk tujuan dalam jangka panjang.

3. PT. Bumi Sarana Utama Cabang Palu harus berupaya untuk meningkatkan kinerja dalam mempertahankan profitabilitasnya. Perusahaan harus dapat mengelola kas dan modal kerja dengan baik agar supaya kebutuhan dana untuk kas dan modal kerja tercukupi dan mengalami peningkatan kas dan modal kerja.

4. PT. Bumi Sarana Utama Cabang Palu dalam menambah kas dan modal kerjanya, harus dapat mengambil kebijakan yaitu dengan mengurangi aktiva tetap, mengalami emisi saham baru, dan meminta pemilik perusahaan untuk menambah modal. Perusahaan dapat menambah hutang jangka panjangnya dalam suatu bentuk upaya menerbitkan obligasi guna menambah modal kerja perusahaan.

\section{REFERENSI}

Bahutala, Lisnawati dan Sepang, Jantje, 2014. Analisis Sumber dan Penggunaan Modal Kerja Pada Kentucky Fried Chicken (KFC) Periode 2009-2012.

Djahidin, Soetjipto, 2010. Laporan Keuangan Perusahaan Ditinjau dari Dasar-Dasar Manajemen Keuangan, CV. Bumi Aksara, Jakarta.

Indriyo, Gitusudarmo, 2007. Dasar-Dasar Manajemen Keuangan Pembelanjaan Perusahaan, CV. Liberty, Yogyakarta.

Kabuhung, Merystika, 2013. Sistem Informasi Akuntansi Penerimaan dan Pengeluaran Kas Untuk Perencanaan dan Pengendalian Keuangan Pada Organisasi Nirlaba Keagamaan, Jurnal EMBA, Vol.1 No.3, Juni 2013, Hal. 339-348, ISSN: 2303-1174.

Maknunah, Jauharul, 2015. Analisis Sistem Informasi Akuntansi Penerimaan dan Pengeluaran Kas Pada Lembaga Pendidikan, Jurnal SMATIKA, Volume 05 Nomor 02 Tahun 2015, ISSN: 2087-0256.

Munawir, S., 2009. Analisa Laporan Keuangan, CV. Liberty, Yogyakarta.

Prastowo, Dwi, Julianty, Rifka, 2012. Analisis Laporan Keuangan Konsep dan Aplikasi, Cetakan Ke-2, AMP-YKPN, Yogyakarta.

Riduwan, 2008. Metode dan Teknik Menyusun Tesis, Cetakan Keenam, Alfabeta, Bandung.

Riyanto, Bambang, 2014. Dasar-Dasar Pembelanjaan Perusahaan, Edisi Ketujuh, Cetakan Ketujuh, BPFE, Yogyakarta.

Rukmini, 2015. Analisis Laporan Sumber dan Penggunaan Kas Pada KUD Tani Makmur Tawangmangu Kabupaten Karanganyar, Jurnal Akuntansi dan Pajak, Vol.16 No.01, Juli 2015, ISSN: 1412-629X. 


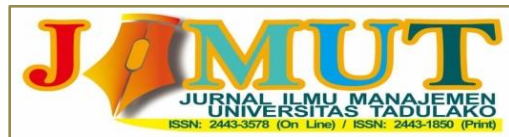

Vol. 7, No 3, Juli 2021, 268-279

Saputra, Andrew Marco, 2013. Analisis Penerapan Sistem dan Prosedur Pengeluaran Kas Pada BPBD Sulawesi Utara, Jurnal EMBA, Vol.1 No.3, September 2013, Hal.32-43, ISSN: 23031174.

Singarimbun, Masri, Sofjan Effendi, 2015. Metode Penelitian Survey, LP3ES, Jakarta.

Sudarsono dan Edilius, 2014. Manajemen Koperasi Indonesia, Rineka Cipta, Jakarta.

Tri Utami, Indah Agustini, 2012. Analisis Sumber dan Penggunaan Modal Kerja Pada Koperasi Pegawai Negeri Balai Kota Samarinda, Jurnal EKSIS, Vol.8 No.2, Agustus 2012: 2168-2357, ISSN: 0216-6437. 